\title{
ANALISIS IMPLEMENTASI ASAS KEPASTIAN HUKUM DALAM PROSES PUTUSAN HAKIM TERKAIT PENGHINAAN MELALUI DUNIA MAYA
}

\author{
Putri Conitatillah Jasmi (1) \\ putrijasmi22@gmail.com ${ }^{(1)}$
}

\section{Universitas Pendidikan Nasional}

\begin{abstract}
Advances in information technology currently have negative impacts such as the existence of information technology. From the existence of this cyber crime promulgated regulation No. 11 of 2008 Regarding Information and Electronic Transactions (UU 11/08). In the Southeast Asia Freedom of Expression Network record, since UU 11/08 was promulgated in 2008 to 31 October 2018 there were 381 victims charged with UU 11/08. The number of cases that occur in Indonesia at this time due to unclear restrictions on criminal acts of defamation contained in Article 27 paragraph (3) of the UU $11 / 08$. The topic raised by the author in this study regarding the implementation of the principle of legal certainty in the process of criminalizing humiliating criminal cases through cyberspace. The author uses this type of normative research by analyzing primary legal materials and secondary legal materials. The results of this study indicate that the provision of defamation in Article 27 paragraph (3) UU 11/08 is a specific provision of the insult provision in Chapter XVI Book II of the Criminal Law Book because the humiliation provisions in UU 11/08 are devoted to insults through cyberspace. However, in Article 27 paragraph (3) UU 11/08 there is no clear explanation and limitation regarding the term of defamation / defamation in question and there is no justification reason therein, which then can lead to different interpretations by law enforcement officers in the criminal process. This is a consideration that Article 27 paragraph (3) UU $11 / 08$ has not been able to provide the fulfillment of the principle of legal certainty.
\end{abstract}

Keywords: Legal certainty, Humiliation, cyberspace.

\section{ABSTRAK}

Kemajuan teknologi informasi saat ini turut membawa dampak negatif seperti adanya bentuk kejahatan dengan berbasis teknologi informasi. Dari adanya kejahatan dunia maya ini diundangkan Undang-Undang Nomor 11 Tahun 2008 Tentang Informasi dan Transaksi Elektronik (UU 11/08). Dalam catatan Southeast Asia Freedom of Expression Network, sejak UU 11/08 diundangkan pada 2008 sampai 31 Oktober 2018 terdapat 381 korban yang dijerat dengan UU 11/08. Banyaknya perkara yang terjadi di Indonesia saat ini karena ketidakjelasan pembatasan tindak pidana penghinaan yang ada di dalam Pasal 27 ayat (3) UU 11/08. Topik yang diangkat oleh penulis dalam penelitian ini mengenai asas kepastian hukum dalam proses pemidanaan kasus tindak pidana penghinaan melalui dunia maya. Penulis menggunakan jenis penelitian normatif dengan menganalisis bahan hukum primer dan bahan hukum sekunder. Hasil penelitian ini menunjukkan bahwa ketentuan penghinaan dalam Pasal 27 ayat (3) UU 11/08 merupakan ketentuan khusus dari ketentuan penghinaan dalam BAB XVI Buku II Kitab Undang-Undang Hukum Pidana. Namun didalam Pasal 27 ayat (3) UU 11/08 tidak ditemui penjelasan dan pembatasan yang jelas 
mengenai istilah penghinaan/pencemaran nama baik yang dimaksud serta tidak terdapat alasan pembenar didalamnya, yang kemudian dapat mengakibatkan penafsiran yang berbeda-beda oleh aparat penegak hukum dalam proses pemidanaan. Hal inilah yang menjadi pertimbangan bahwa Pasal 27 ayat (3) UU 11/08 belum mampu memberikan pemenuhan asas kepastian hukum.

\section{Kata Kunci: Kepastian hukum, Penghinaan, Dunia maya.}

\section{PENDAHULUAN}

Perkembangan dalam era globalisasi dan teknologi informasi saat ini menjadikan teknologi informasi hal yang sangat penting guna mempermudah manusia dalam mendapatkan informasi dan berbagi informasi. Pemanfaatan teknologi informatika dengan lahirnya berbagai situs-situs jejaring sosial seperti website atau bahkan media sosial ini telah digunakan oleh berbagai macam kalangan. untuk kebutuhan masingmasing pengguna. ${ }^{1}$ Adanya kemajuan teknologi informasi ini tidak hanya membawa dampak-dampak positif akan tetapi juga memiliki beberapa dampak negatif yang cukup mengganggu kehidupan sehari-hari. ${ }^{2}$ Dampak negatif yang timbul dari adanya kecanggihan komputer ini terletak pada kesalahan yang ditimbulkan oleh komputer yang dapat merugikan baik tidak disengaja maupun disengaja.

Kejahatan berbasis teknologi informasi ini biasa dikenal dengan kejahatan dunia maya disebut juga dengan Cyber Crime, Cyber Crime. ${ }^{3}$ Dari adanya kejahatan dunia maya ini lah pemerintah akhirnya terdorong untuk mengeluarkan sebuah regulasi berupa Undang-Undang Nomor 11 Tahun 2008 (selanjutnya disebut sebagai UU 11/08). UU 11/08 yang ada sebelumnya telah diubah menjadi Undang-Undang Nomor 19 Tahun 2016 tentang Perubahan Atas Undang-Undang Nomor 11 Tahun 2008 Tentang Informasi dan Transaksi Elektronik (selanjutnya disebut sebagai UU Perubahan UU 11/08).

Tujuan dan maksud dari dikeluarkannya regulasi UU 11/08 ini adalah untuk dapat memberikan perlindungan kepada segala aktivitas masyarakat Indonesia dalam menggunakan dan memanfaatkan adanya teknologi

1 Budi Suhariyanto, 2014, Tindak Pidana Teknologi Informasi (Cybercrime), PT. Raja Grafindo Persada, Jakarta, h.2.

2 A Rahman, "Pengaruh Negatif Era Teknologi Informasi dan Komunikasi pada Remaja (Perspektif Pendidikan Islam)", Fakultas Tarbiyah dan Adab STAIN Parepare, Al-Ishlah Jurnal Studi Pendidikan, Vol 14, No. 1, Januari-Juni 2016,h.24

${ }_{3}$ Maskun, 2013, Kejahatan Siber (Cyber Crime) Suatu Pengantar, Kharisma Putra Utama, Jakarta,h.48 
informasi ini, agar terhindar dari adanya kejahatan dunia maya. Kejahatan dunia maya yang bisa saja terjadi salah satunya adalah penyebaran suatu berita yang didalamnya memiliki muatan penghinaan, hal ini biasa dilakukan saat seorang yang mempunyai akun sosisal media tersebut menuliskan sebuah kata-kata atau bahkan sebuah kalimat pada kolom "status atau caption", berdasarkan apa yang ia pikirkan namun ternyata isi dari tulisan di status media sosialnya tersebut telah menyinggung perasaan pihak lain. Pada hal inilah perbuatan orang tersebut jika berdasarkan Pasal 27 ayat (3) UU 11/08 dapat dikatakan sebagai perbuatan pidana / pencemaran nama baik melalui media sosial.

Materi penghinaan yang termaktub dalam UU 11/08 sesungguhnya adalah ketentuan khusus daripada materi penghinaan yang sebelumnya telah diatur dalam Undang-Undang Nomor 73 Tahun 1958 Tentang Menyatakan Berlakunya Undang-Undang No. 1 Tahun 1946 Tentang Peraturan Hukum Pidana Untuk Seluruh Wilayah Republik Indonesia (selanjutnya disebut KUHP). Materi penghinaan yang diatur dalam UU 11/08 merupakan ketentuan perluasan dari materi penghinaan yang sebagaimana yang berada di dalam KUHP. Dikatakan sebagai perluasan karena jika ditinjau kembali sesungguhnya materi penghinaan sudah termaktub di dalam KUHP BAB XVI tentang Penghinaan akan tetapi penghinaan yang dimaksud dalam Pasal tersebut adalah penghinaan yang dilakukan secara konvensional, sedangkan materi penghinaan yang ada di dalam UU 11/08 adalah penghinaan yang dilakukan dengan melibatkan teknologi informasi.

Sejak awal di undangkannya UU 11/08 perkara pencemaran nama baik yang pertama muncul akibat adanya UU 11/08 terjadi pada tahun 2009 yang telah menjerat Prita Mulyasari. Hal ini terjadi saat Prita Mulyasari menyampaikan pernyataan, ungkapan hatinya, dan keluhannya yang dituangkan melalui surat elektronik (e-mail) mengenai pelayanan kesehatan yang diberikan oleh Rumah Sakit OMNI International Tangerang terhadap dirinya selama ia berobat di rumah sakit tersebut. ${ }^{4}$ Keluhannya dianggap sebagai suatu tindak pidana penghinaan/pencemaran nama baik karena perbuatannya dianggap bertujuan menyerang kehormatan seseorang.

${ }^{4}$ Ernest Sengi, 2018, Kebijakan Formulasi Tindak Pidana Pencemaran Nama Baik Melalui Media Sosial, CV. Pilar Nusantara, Semarang, h.5. 
Prita Mulyasari dalam proses peradilan didakwa oleh Jaksa/Penuntut Umum Kejaksaan Negeri Tangerang dengan Pasal 310-311 KUHP Jo Pasal 27 ayat (3) Jo Pasal 45 ayat (1) UU 11/08 namun hakim Pengadilan Negeri Tangerang pada 29 Desember 2009 memutuskan Prita Mulyasari Bebas. Namun pada upaya hukum Kasasi yang diajukan oleh Pemohon Jaksa/Penuntut Umum Kejaksaan Negeri Tangerang yang diputus hakim pada 30 Juni 2011, menyatakan bahwa Prita Mulyasari besalah melakukan tindak pidana penghinaan/pencemaran nama baik sebagaimana yang termaktub pada Pasal 27 ayat (3) UU 11/08. Lantas Prita Mulyasari mengajukan upaya hukum Peninjauan Kembali dan telah diputus hakim pada 12 September 2012 yang menyatakan bahwa ia bebas dari dakwaan. ${ }^{5}$

Pendapat yang berbeda diantara lembaga pengadilan (Pengadilan Negeri, Mahkamah Agung Kasasi dan Peninjauan Kembali) terkait objek tindak pidana penghinaan / pencemaran nama baik dalam Pasal 27 ayat (3) UU 11/08 ini mengenai kasus Prita Mulyasari tersebut belum memberikan pemenuhan terhadap asas kepastian hukum, sehingga berpeluang untuk disalahtafsirkan atau multitafsir. Sebab hal ini menjadi ironi tatkala sebuah kritik maupun keluhan yang sangat berbeda sekali esensi nya dengan menyerang kehormatan seseorang dapat diancam pidana. Walaupun putusan akhir Peninjauan Kembali Prita Mulyasari dinyatakan bebas, akan tetapi bisa dibayangkan hak-hak Prita Mulyasari yang terenggut karena putusan Kasasi yang menyatakan Prita Mulyasari bersalah dalam putusannya, sesungguhnya putusan tersebut telah merugikan Prita Mulyasari baik secara materil maupun secara immateril.

Catatan Southeast Asia Freedom of Expression Network (selanjutnya disebut sebagai SAFEnet) menyebutkan bahwa sejak UU 11/08 disahkan menjadi sebuah Undang-Undang, jika dihitung sejak tahun 2008 hingga tanggal 31 Oktober 2018 terdapat sekitar 381 orang yang telah menjadi korban sangkaan bahkan hingga dijerat karena UU 11/08 terlebih lagi oleh Pasal 27 ayat (3) yang mengatur mengenai penghinaan dan juga Pasal 28 ayat (2) UU 11/08 yang mengatur mengenai ujaran kebencian. ${ }^{6}$ Bahkan jika

5 Ibid,h. $10-11$.

6 Safenet Voice, [Rilis Pers] PAKU ITE Serukan Hapus Seluruh Pasal Karet UU 11/08, diakses dari laman web http://id.safenetvoice.org/2018/11/rilis-perspaku-ite-serukan-hapus-seluruh-Pasal-karet-uu-ite/ , diakses pada tanggal 15 
ditinjau kembali berdasarkan data yang di keluarkan oleh SAFEnet yang penulis ambil dari laman Tirto.id sejak 2008 hingga Juni 2018, terdapat sebanyak 49,72 persen Pasal yang digunakan sebagai dasar pelaporan adalah Pasal 27 UU 11/08 ayat (3). Marak digunakannya Pasal ini terjadi pada tahun 2016 dengan jumlah sebanyak 54 kasus dan tahun 2017 dengan jumlah sebanyak 32 kasus yang telah dilaporkan. ${ }^{7}$

Meski sudah dilakukan perubahan, UU 11/08, dalam realitanya masih saja mengundang kritik terutama berkaitan dengan Pasal penghinaan atau pencemaran nama baik yang diatur didalamnya. ${ }^{8}$ Banyaknya perkara yang terjadi di Indonesia saat ini karena ketidakjelasan pembatasan tindak pidana penghinaan yang ada di dalam Pasal 27 ayat (3) UU 11/08. Pasal tersebut membuat banyak sekali korban yang terjerat karenanya. Yang ditakutkan saat ini adalah jangan sampai Pasal 27 ayat (3) UU 11/08 ini dinilai sebagai alat represif pemerintah dalam membungkam kritik dan menghambat kebebasan berekspresi masyarakat. Sebagaimana yang telah termaktub dengan jelas dalam konstitusi serta menjadi amanat konstitusi berdasarkan Pasal 28 E ayat (2) Undang-Undang Dasar Republik Indonesia Tahun 1945 (selanjutnya disebut sebagai UUD 1945). Dari hal tersebut perlu dipertimbangkan dengan cermat dan penyidik dalam memproses laporan harus memperhatikan unsur-unsur perbuatan pidana di dalam ketentuan hukum agar kemudian tidak menimbulkan second victim karena kekeliruannya dalam melihat suatu perkara. Banyaknya masalah hukum yang ditemukan ini akibat adanya Pasal 27 ayat (3) UU 11/08 yang sangat berpeluang untuk disalahtafsirkan atau multitafsir menjadi daya tarik tersendiri bagi penulis untuk mengangkat judul “Analisis Implementasi

\section{Asas Kepastian Hukum Dalam Proses Putusan Hakim Terkait Penghinaan Melalui Dunia Maya".}

Berdasarkan latar belakang tersebut maka penulis mengangkat permasalahan yakni, apakah perubahan yang berkaitan dengan ketentuan

Agustus 2019, pada pukul 16.59 WITA.

7 Scholastica Gerintya, Periksa Data Betapa Kecilnya Peluang Untuk Lepas dari Jerat UU 11/08, diakses dari laman web https://tirto.id/betapa-kecilnyapeluang-untuk-lepas-dari-jerat-uu-ite-cVUm , diakses pada tanggal 25 September 2019, pada pukul 17:22 WITA.

8 Muhammad Reza Hermanto, dkk, "Laporan Utama: Revisi UU 11/08 Era Baru Kebebasan Berekspresi", The Indonesian Institute, Update Indonesia Tinjauan Bulanan Ekonomi, Hukum, Keamanan, Politik, dan Sosial, Vol. X, No. 12, Desember 2016,h. 2. 
Pasal 27 ayat (3) dalam UU Perubahan UU 11/08 telah mengimplementasikan asas kepastian hukum dalam putusan hakim terhadap kasus tindak pidana penghinaan melalui dunia maya?

\section{METODE PENELITIAN}

Penelitian yang dilakukan dalam penulisan ini bersifat penelitian hukum normatif, yaitu penelitian yang difokuskan untuk mengkaji hukum yang berlaku dalam masyarakat. ${ }^{9}$ Metode penelitian normatif ini bisa disebut sebagai penelitian kepustakaan, karena penelitian ini dilakukan dengan cara mengkaji dan mendeskripsikan bahan-bahan berupa buku, kamus, jurnal, bahan dari internet, dan perundang-undangan yang berkaitan. Penulis memilih jenis penelitian normatif untuk dapat menganalisis adanya Pasal 27 ayat (3) UU 11/08 yang berpeluang untuk disalahtafsirkan atau multitafsir.

Jenis bahan hukum yang digunakan adalah bahan hukum primer dan bahan hukum sekunder. Bahan hukum primer yakni berupa peraturan perundang-undangan, risalah dalam pembuatan perundang-undangan dan suatu putusan hakim. ${ }^{10}$ Bahan hukum primer yang akan digunakan adalah sebagai berikut:

a. UUD 1945

b. KUHP

c.Undang-Undang Nomor 8 Tahun 1981 tentang Hukum Acara Pidana (selanjutnya disebut sebagai KUHAP)

d. UU 11/08

e. Undang-Undang Nomor 12 Tahun 2011 tentang Pembentukan Peraturan Perundang-undangan (selanjutnya disebut sebagai UU Pembentukan Peraturan Perundang-undangan)

f. UU Perubahan UU 11/08

g. Putusan Pengadilan Negeri Tangerang Nomor 1269/PID.B/2009/PN.TNG Tentang Putusan Pengadilan Tingkat Pertama Atas Perkara Terdakwa Prita Mulyasari

\footnotetext{
${ }^{9}$ H. Ishaq, 2017, Metode Penelitian Hukum dan Penulisan Skripsi, Tesis, serta Disertasi, Alfabeta, Bandung,h. 66.

10 Peter Mahmud Marzuki, Cetakan ke-12 2016, Penelitian Hukum Edisi Revisi, Kencana, Jakarta,h. 181.
} 
h. Putusan Mahkamah Agung Kasasi Nomor 822 K/PID.SUS/2010 Tentang Putusan Mahkamah Agung Kasasi Atas Perkara Terdakwa Prita Mulyasari

i. Putusan Mahkamah Agung Peninjauan Kembali Nomor 225 PK/PID.SUS/2011 Tentang Putusan Mahkamah Agung Peninjauan Kembali Atas Perkara Terdakwa Prita Mulyasari

j. Surat Edaran Kejaksaaan Agung Republik Indonesia Nomor B1179/E/EJP/07/2008 tentang Pola Penanganan Perkara Tindak Pidana Infomasi dan Transaksi Elektronik (selanjutnya disebut sebagai SE Jaksa Agung Penanganan Perkara ITE)

k.Surat Edaran Kepala Kepolisian Negara Republik Indonesia Nomor SE/6/X/2015 Tahun 2015 tentang Penanganan Ujaran Kebencian (Hate Speech) (selanjutnya disebut sebagai SE Hate Speech)

Sementara itu bahan hukum sekunder adalah bahan hukum yang bersifat menjelaskan bahan hukum primer. Bahan hukum sekunder terdiri dari buku hukum termasuk juga karya ilmiah orang lain seperti skripsi, tesis, disertasi hukum, dan jurnal-jurnal hukum. ${ }^{11} \mathrm{Di}$ dalam penelitian ini akan digunakan bacaan atau buku-buku yang berkaitan dengan penghinaan melalui dunia maya. Metode pengumpulan bahan hukum yang digunakan dalam penulisan ini adalah teknik studi kepustakaan bahan hukum tertulis dengan cara membuat catatan kaki berupa kutipan langsung dan kutipan tidak langsung yang di dapat dari buku-buku, jurnal, dan bacaan serta peraturan perundang-undangan yang berkaitan dengan permasalahan ini. Teknik analisis bahan hukum yang digunakan dalam penulisan penelitian ini adalah deskriptif analisis yaitu dengan merumuskan tindakan pemecahan masalah yang sudah teridentifikasikan berdasarkan prinsipprinsip, konsep dan teori hukum serta berdasarkan peraturan perundangundangan.

\section{HASIL PENELITIAN DAN PEMBAHASAN}

\section{Analisis Penerapan Asas Kepastian Hukum Dalam Keputusan} Hakim Terkait Tindak Pidana Penghinaan Melalui Dunia Maya

Hukum harus pasti dan harus adil sebagai pedoman perilaku, hukum harus berisikan hal-hal yang dinilai wajar oleh masyarakat. Hanya dengan bersifat adil

\footnotetext{
${ }^{11}$ Ibid, Hlm. 195-196
} 
dan pasti tersebutlah hukum itu dapat menjalankan fungsinya dengan baik. ${ }^{12}$ F.C Von Savigny di dalam buku Achmad Ali, ia mengidentikkan hukum adalah hukum rakyat sebagai perwujudan dari jiwa rakyat yang merupakan 'kesadaran umum rakyat dan merupakan 'intuisi hidup' dari rakyat. ${ }^{13}$

Asas kepastian hukum penting untuk diperhatikan sebab jika tanpa kepastian hukum, maka masyarakat tidak akan mengetahui bagaimana langkah yang harus dilakukan mengenai hal yang boleh dan tidak boleh dilakukan serta dapat menjadi harapan besar bagi para pencari keadilan. Salah satu dasar pertimbangan dicanangkannya Pasal 27 ayat (3) dalam UU 11/08, karena pembuat undangundang (legislator) berpandangan bahwa Pasal 27 ayat (3) UU 11/08 ini dirasa sangat diperlukan adanya. Mengingat perkembangan teknologi informasi ini juga menyebabkan adanya perkembangan terhadap modus operandi seseorang melakukan tindak pidana dalam dunia maya, khususnya tindak pidana penghinaan melalui dunia maya. Pasal 27 ayat (3) UU 11/08 ini ada disamping ketentuan penghinaan yang ada dalam BAB XVI Buku II KUHP.

Jika dilihat kembali Pasal 27 ayat (3) UU 11/08 kurang memiliki rumusan yang lengkap dan dapat menyebabkan ketidakpastian hukum jika dibandingkan dengan Pasal Penghinaan yang ada dalam KUHP. Maka dari itu, ketika ada hal-hal yang masih perlu dicari kejelasannya, UU 11/08 tetap kembali kepada ketentuan yang berada dalam KUHP. Pasal 27 ayat (3) UU 11/08 tidak memberikan ketentuan atau tidak mengakomodir pengecualian mengenai suatu perbuatan penghinaan/pencemaran nama baik yang dilakukan secara terpaksa untuk membela dirinya atau untuk kepentingan umum, yang menyebabkan penjelasannya harus kembali mengacu dan melihat pada alasan pembenar yang diatur dalam ketentuan yang lebih umum yakni Pasal 310 ayat (3) yang ada dalam KUHP.

Tidak adanya alasan pembenar bagi seseorang untuk dapat melakukan penghinaan/pencemaran nama baik karena terpaksa untuk membela dirinya atau untuk kepentingan umum dalam Pasal 27 ayat (3) UU 11/08 ini mengakibatkan terbukanya berbagai kemungkinan bagi aparat penegak hukum untuk menafsirkan mengenai kapan perbuatan penghinaan/pencemaran nama baik dapat di pidana dan tidak dapat. Jika alasan pembenar ini tidak dipertimbangkan dengan baik dalam perkara penghinaan/pencemaran nama baik, maka hal ini dapat mengekang kebebasan berekspresi.

12 Dominikus Rato, 2010, Filsafat Hukum Mencari : Memahami dan Memahami Hukum, Laksbang Pressindo, Yogyakarta,h.59.

${ }_{13}$ Achmad Ali, Cetakan ke-6 2015, Menguak Teori Hukum (Legal Theory) dan Teori Peradilan (Judicialprudence) Termasuk Interpretasi Undang-Undang (Legisprudence) Volume 1 Pemahaman Awal, Prenamedia Group, Jakarta,h.400. 
Salah satu perkara yang dapat menjadi contoh atas perkara yang sama namun memiliki pertimbangan yang berbeda mengenai alasan pembenar di dalam perkara tersebut adalah putusan perkara Prita Mulyasari dalam putusan Pengadilan Negeri Tangerang Nomor 1269/PID.B/2009/PN.TNG, dalam hal ini perbuatan yang telah dilakukan oleh Prita Mulyasari berdasarkan Judex Factie Pengadilan Negeri Tangerang tersebut dipandang sebagai sebuah kritik terhadap sebuah pelayanan rumah sakit dan hal tersebut dilakukan demi kepentingan umum. Hal berbeda ditafsirkan oleh Mahkamah Agung Kasasi Judex Juris atas putusan Prita Mulyasari dengan Nomor 822 K/PID.SUS/2010. Mahkamah Agung Kasasi menjatuhkan putusan pemidanaan terhadap Prita Mulyasari dengan pertimbangan bahwasannya dalam rumusan Pasal 27 ayat (3) UU 11/08 tidak ada alasan pembenar. Hal yang menjadi permasalahan atas perbedaan yang terjadi diantara judex factie dan judex juris tersebut disebabkan oleh Pasal 27 ayat (3) UU 11/08 yang belum mampu memenuhi asas kepastian hukum dalam mengakomodir adanya alasan peniadaan sifat melawan hukum/ alasan pembenar didalamnya yang kemudian dapat berakibat pada butuhnya penafsiran dalam setiap perkara penghinaan/pencemaran nama baik, sehingga Pengadilan dapat menafsirkannya secara berbeda-beda.

Selaras dengan yang telah dikemukakan sebelumnya bahwa ketentuan dalam Pasal 27 ayat (3) juga tidak mengandung tafsiran yang jelas berkaitan dengan norma yang diaturnya. Unsur penghinaan/pencemaran nama baik dalam Pasal 27 ayat (3) UU 11/08 ini masih terbilang sangat luas karena tidak terdapat suatu pembatasan jelas yang menerangkan bahwa suatu perbuatan tertentu dapat dikatakan sebagai sebuah perbuat penghinaan/pencemaran nama baik. Hal ini sangat penting untuk ditilik kembali karena sebuah perumusan norma hukum terlebih lagi yang memiliki unsur pidana didalamnya tidak boleh perumusannya bersifat ambigu hingga multitafsir.

Menurut Pasal 5 UU Pembentukan Peraturan Perundang-undangan, menyatakan bahwasannya suatu undang-undang yang baik sudah seharusnya untuk memiliki asas diantaranya adalah asas kejelasan rumusan dan asas kedayagunaan/kehasilgunaan. Hal ini bertujuan agar suatu undang-undang dapat diterapkan dengan baik dan juga benar dikemudian hari. Asas tersebut juga penting agar penerapan suatu undang-undang tidak mengalami permasalahan karena ketidakjelasan rumusan yang terkandung didalamnya. Pasal 27 ayat (3) UU 11/08 juga terikat dengan syarat lex certa, yakni konsep yang mengharuskan sebuah kaidah untuk memberikan penjelasan secara rerperinci dan rumusan yang 
cermat atas sebuah perbuatan pidana yang diformulasikan. Karena suatu ketentuan pidana yang tidak jelas dapat menyebabkan ketidakpastian hukum. ${ }^{14}$

Walau telah ada penjelasan yang dicantumkan oleh pembuat undangundang dalam melakukan perubahan UU 11/08 menjadi UU Perubahan UU 11/08, penjelasan Pasal 27 ayat (3) dalam UU Perubahan UU 11/08 yang menjelaskan bahwa ketentuan pada Pasal 27 ayat (3) UU 11/08 ini mengacu pada ketentuan pencemaran nama baik dan/atau fitnah yang termaktub di dalam KUHP. Penjelasan tersebut bukan merupakan solusi atas permasalahan yang ada sekarang, sebab sudah seharusnya formulasi Pasal 27 ayat (3) UU 11/08 ini mencantumkan sebuah penjelasan yang autentik terkait dengan norma yang diaturnya dalam Pasal 27 ayat (3) terlebih lagi mengenai penjelasan yang berkaitan dengan ukuran suatu perbuatan dapat dikatakan sebagai penghinaan/pencemaran nama baik, bukan hanya melakukan duplikasi peraturan yang ada di dalam KUHP. Penjelasan autentik tersebut penting agar ketentuan penghinaan/pencemaran nama baik tidak ditafsirkan secara berbeda-beda. Hal tersebut kemudian dapat memberikan jaminan adanya kepastian hukum dalam penerapan suatu norma hukum, serta dapat menjamin adanya keadilan bagi seseorang apabila perbuatan tersebut semata-mata dilakukan untuk perlindungan diri dan kepentingan umum. Hal yang terpenting adalah agar kebebasan berekspresi yang merupakan amanat konstitusi mendapatkan perlindungan yang adil di muka hukum.

Banyaknya perkara yang terjadi di Indonesia saat ini yang menjadikan Pasal 27 ayat (3) UU 11/08 sebagai dasar pelaporannya pada Kepolisian. Karena Pasal ini tidak dapat memberikan kepastian hukum karena tidak ada penjelasan atas istilah "penghinaan/pencemaran nama baik", hal ini juga karena Kepolisian Republik Indonesia belum mempunyai keseragaman pemahaman terkait hal penghinaan/pencemaran nama baik terlebih lagi jika dilakukan melalui dunia maya, walaupun telah dikeluarkan sebuah regulasi yakni SE Hate Speech.

Komisi Nasional Hak Asasi Manusia Republik Indonesia dalam bukunya yang berjudul penanganan ujaran kebencian menjelaskan bahwasannya penghinaan yang dimaksud didalam SE Hate Speech adalah penghinaan yang ditujukan yang berdasarkan suku, agama, ras, antar golongan, disabilitas, warna kulit dan lain-lain sebagaimana telah diatur didalam SE Hate Speech tersebut. ${ }^{15}$ Berdasarkan penjelasan tersebutlah SE Hate Speech ini kurang cocok dengan Pasal 27 ayat (3) UU 11/08 dan lebih cocok digunakan untuk pedoman internal

${ }^{14}$ Mahrus ali, "Pencemaran Nama Baik Melalui Sarana Informasi dan Transaksi Elektronik (Kajian Putusan MK No. 2/PUU-VII/2009)", Mahkamah Konstitusi Republik Indonesia, Jurnal Konstitusi, Vol. 7, No. 6, Desember 2010,h.122.

15 Tanpa Pengarang, 2016, Buku Saku Penanganan Ujaran Kebencian (Hate Speech), Komisi Nasional Hak Asasi Manusia Republik Indonesia, Jakarta,h.14. 
anggota Kepolisian Republik Indonesia dalam menangani perkara Pasal 28 ayat (2) UU 11/08 yang lebih spesifik mengatur mengenai ujaran kebencian berdasarkan suku, agama, ras dan antar golongan melalui dunia maya.

Ketidakjelasan penjelasan atas istilah "penghinaan/pencemaran nama baik" dalam ketentuan Pasal 27 ayat (3) UU 11/08 tersebut kemudian menyebabkan harus adanya upaya pembuktian dalam proses pemidanaan. Pembuktian merupakan tahapan yang sangat penting baik bagi Jaksa Penuntut Umum maupun bagi terdakwa. Sebab ketika terjadi pertentangan pendapat antara terdakwa dan Jakwa Penuntut Umum didalam persidangan, maka pembuktianlah yang akan menjadi rujukan hakim dalam menjatuhkan pemidanaan terhadap seorang terdakwa.

Berkaitan dengan hal pembuktian dalam perkara pidana diatur di dalam Pasal 183 KUHAP bahwa hakim boleh menjatuhkan suatu pidana apabila telah ada minimal 2 (dua) alat bukti serta wajib ada keyakinan hakim. ${ }^{16}$ Kesalahan dari seorang terdakwa harus terbukti dengan minimal oleh 2 (dua) alat bukti yang sah sebagaimana telah diatur didalam peraturan perundang-undangan. Alat bukti diatur di dalam Pasal 184 Wayat (1) KUHAP, terdapat 5 (lima) jenis alat bukti, yakni Keterangan saksi, Keterangan ahli, Surat, Petunjuk dan Keterangan terdakwa. Alat bukti surat sebagaimana yang telah diatur oleh KUHAP kemudian diperluas kembali berdasarkan ketentuan Pasal 5 ayat (1) dan ayat (2) UU 11/08 yang menyatakan bahwa informasi atau dokumen elektronik ataupun hasil cetaknnya merupakan alat bukti hukum yang dapat diakui dan sah menurut undang-undang.

Berdasarkan Pasal 6 UU 11/08 validasi alat bukti elektronik dalam proses peradilan haruslah memperhatikan syarat-syarat bahwa informasi elektronik atau dokumen elektronik akan dianggap sah sepanjang informasi yang tercantum tersebut dapat diakses, ditampilkan, dijamin keutuhannya dan dapat dipertanggungjawabakan serta keseluruhannya dapat menerangkan suatu keadaan. Syarat-syarat tersebut bersifat kumulatif dan sangat penting untuk dapat mengklasifikasikan apakah barang bukti elektronik tersebut dapat dinyatakan layak untuk dijadikan sebagai alat bukti serta diperbolehkan untuk dihadirkan ke dalam persidangan di Pengadilan. ${ }^{17}$

Ketentuan lebih lanjut mengenai validasi alat bukti ini juga diatur pada angka 2 SE Jaksa Agung Penanganan Perkara ITE menjelaskan bahwasannya alat bukti

16 Yahya Harahap, 2010, Pembahasan Permasalahan dan Penerapan KUHAP: Pemeriksaan Sidang Pengadilan, Banding, Kasasi, dan Peninjauan Kembali, Sinar Grafika, Jakarta,h.280.

17 Anggara, dkk, 2016, Menimbang Ulang Pasal 27 ayat (3) UU 11/08 dalam Putusan Pengadilan: Pertimbangan Putusan Pengadilan Terkait Penggunaan Pasal 27 ayat (3) UU No 11 Tahun 2008 tentang Informasi dan Transaksi Elektronik di Indonesia, Institute for Criminal Justice Reform, Jakarta Selatan,h. 31. 
yang boleh dihadirkan ke persidangan harus berupa informasi atau dokumen elektronik yang menggunakan sistem elektronik yang telah diatur dalam UU 11/08, serta sebelum dijadikan alat bukti harus dimintakan keterangan ahli dari departemen kominfo apakah informasi elektronik atau dokumen elektronik tersebut menggunakan sistem elektronik sesuai dengan ketentuan yang diatur dalam UU 11/08. Jika telah dinyatakan sesuai maka dapat dijadikan alat bukti yang setara dengan keterangan saksi, ahli atau surat. Namun jika diyatakan tidak sesuai, maka informasi atau dokumen elektronik tersebut tidak dapat dijadikan alat bukti, tetapi hanya menjadi barang bukti.

Apabila telah memenuhi sekurang-kurangnya 2 (dua) alat bukti yang sah, maka selanjutnya dalam menjatuhkan putusan haruslah mendapatkan keyakinan hakim bahwasannya tindak pidana tersebut benar adanya telah terjadi, serta yang melakukan tindak pidana tersebut adalah terdakwa yang didakwa di Pengadilan. Keyakinan hakim wajib harus ada dalam proses ditetapkannya suatu putusan pengadilan. Hakim dalam menilai dan memberikan keyakinannya haruslah secara obyektif menilai seluruh fakta-fakta dan keadaan yang terdapat didalam persidangan. ${ }^{18}$ Baik antara alat bukti yang sah dan keyakinan hakim saling berkaitan satu sama lain, atas dasar itulah keyakinan hakim dalam mengeluarkan putusan tidak diperbolehkan apabila hanya didasarkan pada keyakinan semata, melainkan harus tetap memperhatikan alat bukti yang ada dalam persidangan.

Terhadap suatu norma yang dinilai multitafsir maka keyakinan hakim tersebut dapat dihasilkan dari proses persidangan dan pembuktian melalui 2 (dua) alat bukti yang sah dan disamping itu dapat juga melakukan proses penafsiran. Adapun upaya-upaya penafsiran yang dapat dilakukan adalah sebagai berikut: 19

1.Penafsiran tata bahasa atau gramatikal yakni upaya menafsirkan dengan menetapkan arti kata dalam undang-undang yang kurang jelas dengan menggunakan bahasa sehari-hari untuk mendapatkan kejelasan.

2.Penafsiran Sejarah adalah upaya menafsirkan dengan menetapkan arti undang-undang berdasarkan tujuan dibentuknya undang-undang tersebut. Penafsiran sejarah dapat dibedakan menjadi 2 (dua) macam, yakni:

a.Penafsiran menurut sejarah undang-undang, penafsiran ini bersumber pada keterangan pemerintah sebagai pengantar rancangan undangundang, pandangan-pandangan umum, dan pembahasan Pasal demi Pasal di lembaga legislatif.

18 Jerol Vandrixton Lintogareng, "Analisa Keyakinan Hakim Dalam Pengambilan Keputusan Perkara Pidana Di Pengadilan”, Fakultas Hukum Universitas Sam Ratulangi, Jurnal Lex Crimen, Vol. II, No. 3, Juli 2013,h.24.

19 Donald Albert Rumokoy dan Frans Maramis, 2014, Pengantar IImu Hukum, RajaGrafindo Persada, Jakarta,h.158-162. 
b.Penafsiran menurut sejarah hukum, penafsiran dengan menyelidiki keseluruhan latar belakang lembaga hukum yang diatur di dalamnya.

3.Penafsiran Sistematis adalah upaya menafsirkan dengan menetapkan arti undang-undang dengan melihat hubungan antara suatu Pasal atau undang-undang dengan Pasal atau undang-undang lain.

4.Penafsiran Teleologis adalah upaya menafsirkan dengan menetapkan arti undang-undang berdasarkan tujuannya ke masyarakat (sosial).

Menafsirkan suatu Pasal dalam peraturan perundang-undangan yang kurang jelas sudah menjadi hak dan kewajiban Hakim. Biasanya Hakim menggunakan upaya penafsiran yang diajarkan dalam ilmu hukum. Berdasarkan 4 (empat) macam upaya penafsiran suatu Pasal yang telah di paparkan diatas jika dikaitkan dengan adanya Pasal 27 ayat (3) UU 11/08 yang masih dinilai multitafsir tersebut, maka upaya penafsiran yang cocok untuk diterapkan atas Pasal 27 ayat (3) UU 11/08 adalah penafsiran tata bahasa / gramatikal dengan memberikan makna yang logis pada ketentuan yang masih kabur dengan bahasa yang berlaku.

Pendapat tersebut dikuatkan kembali oleh pendapat Johny Ibrahim dalam bukunya yang menyatakan bahwa pada umumnya penafsiran tata bahasa / gramatikal ini digunakan oleh hakim dengan memberikan makna pada suatu peraturan hukum melalui penalaran hukum untuk kemudian diterapkan pada norma yang kurang jelas. ${ }^{20}$ Penafsiran hukum dapat dilakukan oleh Hakim selama belum dilakukan perubahan ketentuan penjelasan atas Pasal 27 ayat (3) UU Perubahan UU 11/08 dan belum diberikan penjelasan yang benar-benar jelas, tidak ambigu dan tidak multitafsir atas Pasal 27 ayat (3) UU 11/08.

Namun karena belum adanya peraturan yang mewajibkan hakim untuk menggunakan penafsiran tata bahasa / gramatikal, hal ini menjadi sia-sia sebab hakim masih bebas untuk memilih upaya penafsirannya sendiri. Perbedaan pilihan upaya penafsiran hukum oleh hakim yang disebabkan tidak adanya kesamaan pandangan tentang metode penafsiran yang digunakan, akan menyebabkan penafsiran yang beragam oleh hakim terhadap satu ketentuan norma kabur yang sama sekalipun.

\section{KESIMPULAN}

Berdasarkan penjelasan yang telah diuraikan diatas dapat dirarik 2 (dua) kesimpulan, yakni: Bahwa meski telah dilakukan perubahan dengan ditambahnya ketentuan penjelasan atas Pasal 27 ayat (3) UU 11/08 dalam UU Perubahan UU 11/08, namun tetap hal itu belum mampu memberikan pemenuhan asas kepastian hukum dalam proses pemidanaan perkara penghinaan melalui dunia maya yang disebabkan: Pertama, karena tidak

20 Johny Ibrahim, 2011, Teori \& Metodologi Penelitian Hukum Normatif, Bayumedia, Malang, h.221. 
adanya pembatasan yang jelas mengenai perbuatan penghinaan/pencemaran nama baik yang disebut dan dimaksud oleh Pasal 27 ayat (3) UU 11/08 terutama pengecualian yang mengatur mengenai tindak pidana penghinaan/pencemaran nama baik dalam Pasal 27 ayat (3) UU 11/08. Kedua, hakim masih belum memiliki kesamaan pandangan atau dalam kata lain masih banyaknya cara atau metode yang dapat digunakan oleh hakim untuk dapat menafsirkan Pasal 27 ayat (3) UU 11/08 dalam proses persidangan.

Berdasarkan kesimpulan yang telah dipaparkan di atas, penulis mengajukan beberapa saran yang dapat dilakukan selanjutnya, yakni: Pemerintah khususnya Dewan Perwakilan Rakyat harus segera melakukan perubahan kembali pada Pasal 27 ayat (3) UU 11/08 di masa yang akan datang dengan menghapus penjelasan yang sudah ada sekarang dan memberikan penjelasan baru yang lebih terperinci serta pembatasan terkait istilah "penghinaan/pencemaran nama baik". Hal ini penting dilakukan untuk menjamin adanya kepastian hukum dan perlindungan terhadap kebebasan berekspresi bagi masyarakat Indonesia jika suatu perbuatan penghinaan/pencemaran nama baik tersebut dilakukan semata-mata karena terpaksa untuk membela diri atau untuk kepentingan umum. Hal ini juga dilakukan agar masyarakat mengetahui batasan-batasan yang jelas dalam menggunakan media sosial. Harus diterbitkan Surat Edaran Mahkamah Agung Republik Indonesia untuk menjadi pedoman internal bagi seluruhh Hakim Republik Indonesia yang isinya mengatur mengenai metode penafsiran hukum atas ketentuan Pasal 27 ayat (3) UU 11/08 serta mengatur mengenai upaya pembuktian.

\section{DAFTAR PUSTAKA}

Buku:

Ali, Achmad, Cetakan ke-6 2015, Menguak Teori Hukum (Legal Theory) dan Teori Peradilan (Judicialprudence) Termasuk Interpretasi Undang-Undang (Legisprudence) Volume 1 Pemahaman Awal, Prenamedia Group, Jakarta

Anggara, dkk, 2016, Menimbang Ulang Pasal 27 ayat (3) UU ITE dalam Putusan Pengadilan: Pertimbangan Putusan Pengadilan Terkait Penggunaan Pasal 27 ayat (3) UU No 11 Tahun 2008 tentang Informasi dan Transaksi Elektronik di Indonesia, Institute for Criminal Justice Reform, Jakarta Selatan

Faisal, 2010, Menerobos Positivisme Hukum, Rangkang Education, Yogyakarta 
Harahap, Yahya, 2010, Pembahasan Permasalahan dan Penerapan KUHAP: Pemeriksaan Sidang Pengadilan, Banding, Kasasi, dan Peninjauan Kembali, Sinar Grafika, Jakarta

Ibrahim, Johny, 2011, Teori \& Metodologi Penelitian Hukum Normatif, Bayumedia, Malang

Ishaq, H., 2017, Metode Penelitian Hukum dan Penulisan Skripsi, Tesis, serta Disertasi, Alfabeta, Bandung

Maskun, 2013, Kejahatan Siber (Cyber Crime) Suatu Pengantar, Kharisma Putra Utama, Jakarta

Marzuki, Peter Mahmud, 2016, Penelitian Hukum Edisi Revisi, Kencana, Jakarta

Rato, Dominikus, 2010, Filsafat Hukum Mencari : Memahami dan Memahami Hukum, Laksbang Pressindo, Yogyakarta

Rumokoy, Donald Albert, dan Maramis, Frans, 2014, Pengantar IImu Hukum, RajaGrafindo Persada, Jakarta

Sengi, Ernest, 2018, Kebijakan Formulasi Tindak Pidana Pencemaran Nama Baik Melalui Media Sosial, CV. Pilar Nusantara, Semarang

Suhariyanto, Budi, 2014, Tindak Pidana Teknologi Informasi (Cybercrime), PT. Raja Grafindo Persada, Jakarta

Tanpa Pengarang, 2016, Buku Saku Penanganan Ujaran Kebencian (Hate Speech), Komisi Nasional Hak Asasi Manusia Republik Indonesia, Jakarta

Jurnal :

Ali, Mahrus, Vol. 7, No. 6, Desember 2010, Pencemaran Nama Baik Melalui Sarana Informasi dan Transaksi Elektronik (Kajian Putusan MK No. 2/PUU-VII/2009), Jurnal Konstitusi, Mahkamah Konstitusi Republik Indonesia

Hermanto, Muhammad Reza, dkk, Vol. X, No. 12, Desember 2016, Laporan Utama: Revisi UU 11/08 Era Baru Kebebasan Berekspresi, The Indonesian Institute, Update Indonesia Tinjauan Bulanan Ekonomi, Hukum, Keamanan, Politik, dan Sosial

Lintogareng, Jerol Vandrixton, Vol. II, No. 3, Juli 2013, Analisa Keyakinan Hakim Dalam Pengambilan Keputusan Perkara Pidana Di Pengadilan, Jurnal Lex Crimen, Fakultas Hukum Universitas Sam Ratulangi

Rahman, A, Vol 14, No. 1, Januari-Juni 2016, Pengaruh Negatif Era Teknologi Informasi dan Komunikasi pada Remaja (Perspektif Pendidikan Islam), Al-Ishlah Jurnal Studi Pendidikan, Fakultas Tarbiyah dan Adab STAIN Parepare

\section{Peraturan Perundang-Undangan}

Undang-Undang Dasar Republik Indonesia Tahun 1945

Undang-Undang Republik Indonesia Nomor 73 Tahun 1958 Tentang Menyatakan Berlakunya Undang-Undang No. 1 Tahun 1946 Republik Indonesia Tentang Peraturan Hukum Pidana Untuk Seluruh Wilayah Republik Indonesia (Lembaran Negara Tahun 1958 Nomor 127 dan Tambahan Lembaran Negara Nomor 1660)

Undang-Undang Republik Indonesia Nomor 8 Tahun 1981 tentang Hukum Acara Pidana (Lembaran Negara Tahun 1981 Nomor 76 dan Tambahan Lembaran Negara Nomor 3209).

Undang-Undang Republik Indonesia Nomor 11 Tahun 2008 tentang Informasi dan Transaksi Elektronik (Lembaran Negara Tahun 2008 
Nomor 58 dan Tambahan Lembaran Negara Nomor 4843)

Undang-Undang Republik Indonesia Nomor 12 Tahun 2011 tentang Pembentukan Peraturan Perundang-undangan (Lembaran Negara Tahun 2011 Nomor 82 dan Tambahan Lembaran Negara Nomor 5234)

Undang-Undang Republik Indonesia Nomor 19 Tahun 2016 tentang Perubahan Atas Undang-Undang Nomor 11 Tahun 2008 Tentang Informasi dan Transaksi Elektronik (Lembaran Negara Tahun 2016 Nomor 251 dan Tambahan Lembaran Negara Nomor 5952)

Putusan Pengadilan Negeri Tangerang Nomor 1269/PID.B/2009/PN.TNG Tentang Putusan Pengadilan Tingkat Pertama Atas Perkara Terdakwa Prita Mulyasari

Putusan Mahkamah Agung Kasasi Nomor 822 K/PID.SUS/2010 Tentang Putusan Mahkamah Agung Kasasi Atas Perkara Terdakwa Prita Mulyasari

Putusan Mahkamah Agung Peninjauan Kembali Nomor 225 PK/PID.SUS/2011 Tentang Putusan Mahkamah Agung Peninjauan Kembali Atas Perkara Terdakwa Prita Mulyasari

Surat Edaran Kejaksaaan Agung Republik Indonesia Nomor B1179/E/EJP/07/2008 tentang Pola Penanganan Perkara Tindak Pidana Infomasi dan Transaksi Elektronik

Surat Edaran Kepala Kepolisian Negara Republik Indonesia Nomor SE/6/X/2015 Tahun 2015 tentang Penanganan Ujaran Kebencian (Hate Speech)

\section{Internet}

Safenet Voice, [Rilis Pers] PAKU ITE Serukan Hapus Seluruh Pasal Karet UU ITE, diakses dari laman web http://id.safenetvoice.org/2018/11/rilis-pers-paku-ite-serukan-hapusseluruh-Pasal-karet-uu-ite/, diakses pada tanggal 15 Agustus 2019, pada pukul 16.59 WITA.

Scholastica Gerintya, Periksa Data Betapa Kecilnya Peluang Untuk Lepas dari Jerat UU 11/08, diakses dari laman web https://tirto.id/betapakecilnya-peluang-untuk-lepas-dari-jerat-uu-ite-cVUm, diakses pada tanggal 25 September 2019, pada pukul 17:22 WITA. 